\title{
Influence of Environmental Temperature on Milk Production in the Italian Mediterranean Buffalo
}

\author{
Luigi Zicarelli*
}

\author{
Dipartimento di Medicina Veterinaria e Produzioni Animali, Università Federico II, Napoli, Italy
}

\begin{abstract}
The purpose of this study is to verify the influence of ambient temperature on the percentage of subjects with decreased production, compared to what was recorded in the previous 7-10 days. The data processed in the 2017-2020 period was studied in a company in the lower Caserta area that raises 3000 animals per year, of which 1300 are dairy. All this was possible thanks to the daily collection of production data recorded in the milking parlor, using RFID technology, and then transferred to management software, essential for the farmer for problem-solving decisions. The buffalo is of tropical origin, and there are many factors that influence the production of the Italian Mediterranean buffalo, first of all, seasonality, temperature, health, or the combination of all these elements. For these reasons, it seemed appropriate to focus our attention on the influence of ambient temperature on production. In the first three years of observation, it emerged that as the ambient temperature decreases, the percentage of subjects that recorded a drop in production compared to the previous figure increases. However, this was not found in 2020, when the covered structures were equipped with permanent bedding consisting of straw. This shows that it is important to guarantee the state of wellbeing so as not to penalize the production of milk for the PDO buffalo mozzarella, which represents an interesting source of income.
\end{abstract}

Keywords: Buffalo, temperature and milk production, use of straw for litter, buffalo sensitivity to low temperatures, buffalo milk.

\section{INTRODUCTION}

With the last glaciation of the Pleistocene, the buffalo disappeared from Europe and North Africa and migrated to tropical and subtropical areas characterized by higher temperatures and probably more suited to its physiological needs. Over $99 \%$ of the buffalo population is, in fact, reared in tropical and subtropical areas [1].

This phenomenon did not involve the bovine, which adapted to climatic variations and did not migrate from the areas of the old continent and Asia, settling in the cold and mild areas, where it evolved as Bos Taurus, or in the hot and arid zones, which were populated by the Bos indicus.

For this reason, the researchers mainly studied the influence of high temperatures on the productive and reproductive efficiency of the buffalo. However, the species is present, albeit to a limited extent (about $0.2 \%$ ), even in temperate areas characterized by winters with low temperatures such as in Europe (Italy, Bulgaria, Romania, Holland, France, Germany) and recently in Canada.

The effects of low temperatures studied in Italy have been highlighted:

*Address correspondence to this author at the Dipartimento di Medicina Veterinaria e Produzioni Animali, Università Federico II, Napoli, Italy; Tel: 3346939579; E-mail: zicarell@unina.it

ISSN: 1927-5196 / E-ISSN: 1927-520X/21 a) an increase in the incidence of double ovulations and a reduction in the efficiency of instrumental insemination, especially if performed in OBMS farms $[2,3]$;

b) an increase in basal metabolism to regulate thermoregulation with an increase in $\mathrm{T} 3$ and $\mathrm{T} 4$ and a decrease in TSH [4];

c) a reduction in reproductive activity also because the colder periods coincide with the daily increase in daytime hours $[2,6]$

d) an increase in lipomobilization (cholesterol and NEFA) useful for producing endogenous heat necessary to guarantee thermoregulation with adverse effects on reproductive performance [4].

That said, it is known that the disadvantages of the "Out of season breeding mating strategy" (OBMS) are represented by the decrease infertility due to the onset of spring anestrus (failure to resume the estrus cycle after calving), with a consequent increase in part [3]. The spring anestrus, which affects both females and bulls, is much more severe than the autumn anestrus, which occurs after an evident estrus with nonconception due to a decrease in the pulsatility of the $\mathrm{LH}$ with the consequent establishment of a state of ovarian inactivity.

\section{EXPERIMENTAL RESEARCH}

In the areas of southern Italy, it is known that when temperatures rise in June, for a few days in the 


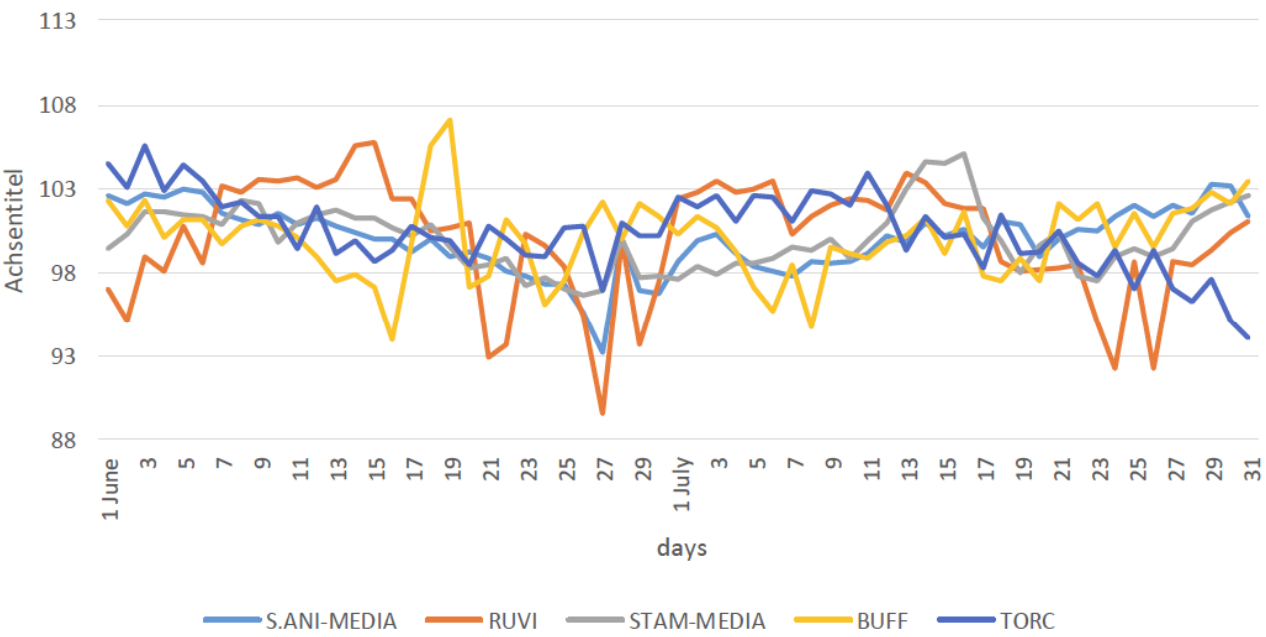

Figure 1: Daily production recorded in June and July expressed as a percentage vs the average for the respective month.

buffaloes, there is a reduction in buffalo production compared to the monthly average, as can be seen in Figure 1. After June 22, for example, a decline of around $1.215 \%$ can be observed.

This value is minimal if we consider that since the farms are subject to the OBMS, the month of June coincides with the period of maximum crowding of the milking parlor and, therefore, of stress for both the buffaloes and the milking staff.

In the warm months, it should be emphasized that in dairy cows, there is a quantitative reduction that exceeds $3 \%$ and a decrease in the percentage of proteins which, from average values of $3.4 \%$, reaches $3.35 \%$; this occurs despite the fact that in recent years Jersey cows, notoriously less sensitive to high temperatures, have been introduced to dairy farms.

In the buffalo, the slight drop in production does not change the yield to the dairy, as can be seen from Table 1 and Figure 2. From this short introduction and from the studies reported, it appears that what has been learned about the influence of high temperatures in dairy cattle cannot be extrapolated to buffalo.

In the past, field research conducted in the Upper Casertano, an area characterized by cold temperatures in the winter months, showed an improvement in production and fertility when a covered area of the company was equipped with heating for four consecutive years. This resulted in an increase in herd fertility from 40 to $70 \%$ and reduced the calving interval from around 530 days to 475 days, and increased milk production by $7 \%$. The cost of the convectors has been amply repaid by the increase in milk production and the increase in births [5]. When the cold months arrive, many buffaloes, even in an advanced stage of lactation, show a smell of acetone, a sign of the presence of acetonemia, probably attributable to lipolysis, triggered by coping with the increase in energy needs caused by the lowering It has also been shown in subsequent research $[5,8]$ that the production of milk and dry matter intake does not decrease during the summer months contrary to what recorded in the dairy cow.

In the course of evolution, buffaloes have acquired some characteristics that allow them to live in warm and humid areas. The optimal temperature of this species is in fact between $15^{\circ} \mathrm{C}$ and $30^{\circ} \mathrm{C}$. Therefore, the evolutionary process has made this species more active and more productive in the warmer months, as long as the farms are equipped with suitable means of protection from the sun's rays [9]. In

Table 1: Dairy Yield Values (\%) in 5 Farms between May and August

\begin{tabular}{|c|c|c|c|c|c|}
\hline & Gall & Ruv & tor & S.A. & S.T. \\
\hline \hline May & 23.92 & 25.12 & 23.28 & 24.39 & 24.71 \\
\hline June & 24.9 & 25.82 & 24.27 & 25.61 & 25.68 \\
\hline July & 25.05 & 26.09 & 24.64 & 25.62 & 25.46 \\
\hline August & 25.26 & 26.44 & 24.63 & 25.25 & 24.97 \\
\hline
\end{tabular}




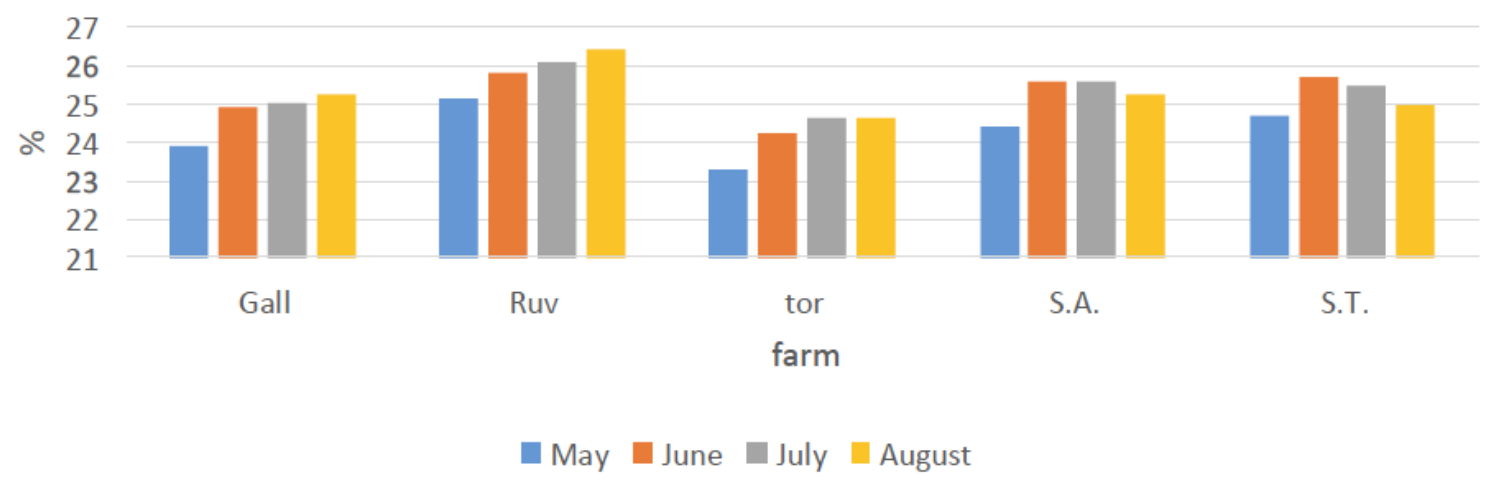

Figure 2: Dairy yield values (\%) in 5 farms between May and August.

order for the research results to be clearer, it should be emphasized that buffalo fertility improves with decreasing hours of light, regardless of temperature, because it is a negative photoperiod species. The peak of fertility in the OBMS herds occurs between July and September and between September and January in the non-OBMS herds, which record the calving season between July and December - January; in this period, about $70 \%$ of births are recorded and, north of the equator, in both temperate and tropical areas, the remaining $30 \%$ give birth between February and June. Cattle, on the other hand, have positive photoperiodic fertility and the lowest conception rate between July and August. Ultimately, just when the fertility of the dairy cow is best (January - June), that of the buffalo is worst. When the OBMS technique is adopted, most of the conception in the buffalo occurs between July and September, the time of year when the cow's fertility records the lowest values. Ultimately in the cold months, the bovine is more fertile while the buffalo is less fertile also because these months coincide with the period in which the hours of light progressively increase.

The buffalo's sensitivity to cold also involves calves, so much so that the premises intended for them must be protected from low temperatures. Recently, from field observations, a significant reduction in the mortality of calves placed in closed rooms protected from cold air currents in single-seat cages was observed. Recall that the containment of mortality in bovine calves is observed when they are placed in single cages placed outdoors. The peak of production in OBMS buffalo, as has already been reported, contrary to what is observed in cattle, occurs in the summer period (between June and August), just when $\mathrm{T}^{\circ}$ and $\mathrm{THI}$ are similar to those of tropical countries. In cattle, taking, for example, the Friesian breed, more sensitive than other breeds to thermal stress, when the
$\mathrm{THI}$ is higher than $70-72 \%$, an increase in respiratory rate, sweating, body temperature, and an increase in intake is observed of water per $\mathrm{kg}$ of dry matter ingested.

This stressful condition is associated with a decrease in production and an impoverishment of the milk produced due to the decrease, especially in the protein content. Under the same climatic conditions, the so-called "fresh" cows, i.e., cows still in the catabolic phase of lactation (generally in the first 60-80 days after calving), seem to be a little affected temperature-humidity effect. The "fresh" ones, in fact, produce part of the milk using the endogenous substances that derive from endogenous catabolism (8 liters of FCM milk per $\mathrm{kg}$ of weight lost) and from what they take in the manger while those who have given birth for over 90 days depend exclusively on what it ingests. The lower food intake, therefore, penalizes the latter much more than the former, and this determines the production of milk in a mass of worse quality because the milk of the cows that have given birth for more than 3-4 months, which produce the richest milk, has a lesser percentage of the total, while the "fresh" one, less rich in fats and proteins, will prevail [8]. The cow also reduces dry matter consumption to reduce endogenous heat. However, the worsening of the chemical composition of herd milk depends on the percentage of fresh buffaloes and on the percentage of cows that gave birth at least $130 / 140$ days earlier. During the warm months, the content of fats and proteins decreases, and only in October the protein and lipid titles return to normal levels. This does not happen in all cattle breeds; for example, in Jersey and Brown (in 1800, in the USA, Brown was crossed with Jersey), this does not happen. It is for this reason that there are a certain number of Jersey cows on the Friesian farms to prevent milk from being paid less in summer; in the blood of the Jersey cows, there is the 
blood of the zebu because 20-30000 years before Christ there was an immigration of Pakistanis [10] (it.wikipedia.org >wiki> Razza_bovina_Piemontese), and therefore of zebu, in Europe (8,500 years ago the islands of Jersey were hills that were part of Normandy; www.agraria.org srazzebovinelattes jersey). In the summer months, Friesians begin to hyperventilate, while Brown and Jerseys do not exhibit the same behavior. In the buffalo species, on the other hand, it was observed that for the same space $\left(\mathrm{m}^{2} /\right.$ head), parity of calving and rationing, the production of milk at 135 days from calving, which corresponds to half lactation, is not negatively influenced by summer temperatures but from winter ones [7, 8]. During the winter, a lower milk production corresponds to greater ingestion of dry matter, which results in a worse conversion of the dry matter into milk. It is probable that part of the dry matter, and therefore the energy contained in it, is used to satisfy the greater needs deriving from low ambient temperatures, precisely because the buffalo is a species that prefers the heat. Furthermore, contrary to what happens in the dairy cow, the buffalo does not negatively modify the quality of the summer milk to the point that the mozzarella produced in the summer is even tastier and more pleasant to the consumer. The greater intake of dry matter during the summer can also depend on increased sexual activity. Cold, on the other hand, increases body heat loss and neonatal mortality and affects thyroid function $[4,12]$. Negative T4 levels affect estrogen and progesterone in the follicular fluid, reducing fertility.

The buffalo, however, to defend themselves from high temperatures, must have the opportunity to immerse themselves in water or mud and needs shaded areas that are essential for optimizing thermoregulation during the summer season. The most effective means of dissipating heat in this species is water or mud [13]. Many farms, in fact, are equipped with tanks where buffaloes immerse themselves in the summer months. Experimental research has shown that their use significantly reduces the embryonic mortality rate and improves fertility [14, 15]. However, the availability of water pools has not led to improvements in the quantity and quality of milk.

On the basis of what has been reported and in consideration of the fact that researchers have so far considered the influence of high temperatures on the productive performance of buffalo. In a farm in Caserta, it seemed appropriate to verify the influence of the environmental temperature on the percentage of subjects with modified production, compared to that recorded in the previous survey.

\section{MATERIALS AND METHODS}

The breeding of the lower Caserta area where the study was carried out raises 3000 animals, of which 1300 milk buffaloes. The individual milk production is recorded daily, thanks to the electronic identification of the animals using RFID technology (Radio-Frequency Identification), or technology for the identification and/or automatic archiving of information relating to the subjects (automatic identification and data acquisition, AIDC) based on the storage capacity of data through tags or transponders and the ability of the tags to respond to remote requests from special readers, the presence of milk meters in the milking parlor and the management of milking data through dedicated management software .

The milk produced between delivery and the day of the survey (P-G) was estimated at the end of the 270 days of lactation from three to five times a month in subjects with a lactation duration greater than 90 days. For this purpose, software was used, validated on over 10,000 cases, in which the reliability between P-G and the total quantity of milk produced in 270 days was verified. The methodology is reliable because, between 90 and 270 days, the decrease in production is linear. With each survey, it was, therefore, possible to verify with respect to the previous estimate whether there had been an increase or a decrease, and this allowed to calculate each time the percentage of buffaloes that had registered an increase or a decrease. These calculations were made in 2017, 2018, 2019, and 2020. The case study involved data from 1300 lactating buffaloes per year.

Unlike the previous three years, starting from January 2020, the internal structures were equipped with permanent bedding consisting of straw.

In the farm where the test was conducted, lactating animals have shaded shelters of $15 \mathrm{~m} 2 /$ head and 30 m2 / head respectively between November and April and between May and October, and swimming pools in which to immerse themselves in the summer months. The regression analysis was performed between the daily temperature and the percentage of subjects (total, pregnant and empty) who registered a decrease compared to the previous survey; the same procedure (regression analysis) was used to evaluate any 
associations between the monthly average temperature and the monthly average of the percentage of subjects that registered a decrease compared to the previous survey. Student's "t" test was used among the monthly percentage values of the subjects (total, pregnant and empty) who registered a decrease compared to the previous survey at temperatures above or below the monthly average. The daily temperature was detected by [16].

\section{RESULTS AND DISCUSSION}

For each year, for the sake of brevity, despite having processed the daily data, only the average values of each month will be reported.

The average temperatures of the years considered were not different after being statistically elaborated with the 'Student test'.

The values of the correlation coefficients found between the monthly average temperatures and the percentage of buffaloes, both pregnant and open, which recorded a decrease in production compared to previous data, were always very significant and negative between 2017 and 2019 (Tables 2, 3, and 4 and Figures 3, 4 and 5 respectively in 2017, 2018, 2019). In conclusion, as the ambient temperature decreases, the percentage of subjects who decreased production compared to the previous data increased. In
2020 (Table 5 and Figure 6), there is no relationship, except a significance of $5 \%$ for pregnant buffaloes, between the monthly average temperatures and the percentage of both pregnant and empty buffaloes that recorded a decrease in production. Compared to the previous ones, given because the covered structures were equipped with permanent straw bedding in the colder months.

Suppose we divide the percentage of subjects who have decreased production between temperatures $\left(^{\circ}\right.$ C) above and below the average (Table 6 ) between 2017 and 2019. In that case, the higher temperatures correspond to a lower value both for the total and for the pregnant subjects and empty. In 2020, the differences disappeared. In non-pregnant subjects, the difference between high and low temperatures is lessened.

We underline that below $19{ }^{\circ} \mathrm{C}$ the pregnant subjects showed a higher value of the percentage of subjects who decreased the production in pregnant animals (44.70 and 39.18; $P<0.05)$ while above this temperature $(19 \mathrm{C})$, the difference disappears $(30.90$ and 33.8; ns) in open subjects.

Finally, as each degree centigrade increases, the percentage of subjects flexing production decreases by $0.62 \%, 1.07 \%$, and $0.26 \%$, respectively, for the total number of pregnant and empty buffaloes (Table 7 and Figure 6).

Table 2: Average Monthly Temperature in 2017 and Total Decrease Rate (\% Total) and Relative to Pregnant Ones (\% Pregnant) and Empty Ones (\% Empty), which Recorded a Decrease in Milk Production

\begin{tabular}{|c|c|c|c|c|}
\hline & ${ }^{\circ} \mathrm{C}$ & $\%$ total & $\%$ pregnant & $\%$ empty \\
\hline January & 8.75 & 57.06 & 59.39 & 55.52 \\
\hline February & 10.33 & 44.46 & 49.77 & 42.26 \\
\hline March & 13.67 & 43.36 & 50.67 & 40.47 \\
\hline April & 15.00 & 51.20 & 55.21 & 51.95 \\
\hline May & 19.25 & 43.16 & 36.29 & 44.88 \\
\hline June & 24.75 & 43.12 & 41.99 & 42.96 \\
\hline July & 26.40 & 45.09 & 40.33 & 47.26 \\
\hline August & 27.67 & 31.46 & 36.22 & 29.50 \\
\hline September & 22.40 & 32.99 & 39.84 & 30.97 \\
\hline October & 17.33 & 37.58 & 53.23 & 38.37 \\
\hline November & 11.50 & 52.61 & 69.13 & 49.17 \\
\hline December & 8.33 & 47.21 & 54.07 & 45.53 \\
\hline Value of "r" & & 0.679 ** & 0.791 ** & 0.560 * \\
\hline
\end{tabular}

$\left.{ }^{* *} P<0.05 ;{ }^{*} P<0.05 \div 0.1\right)$. 


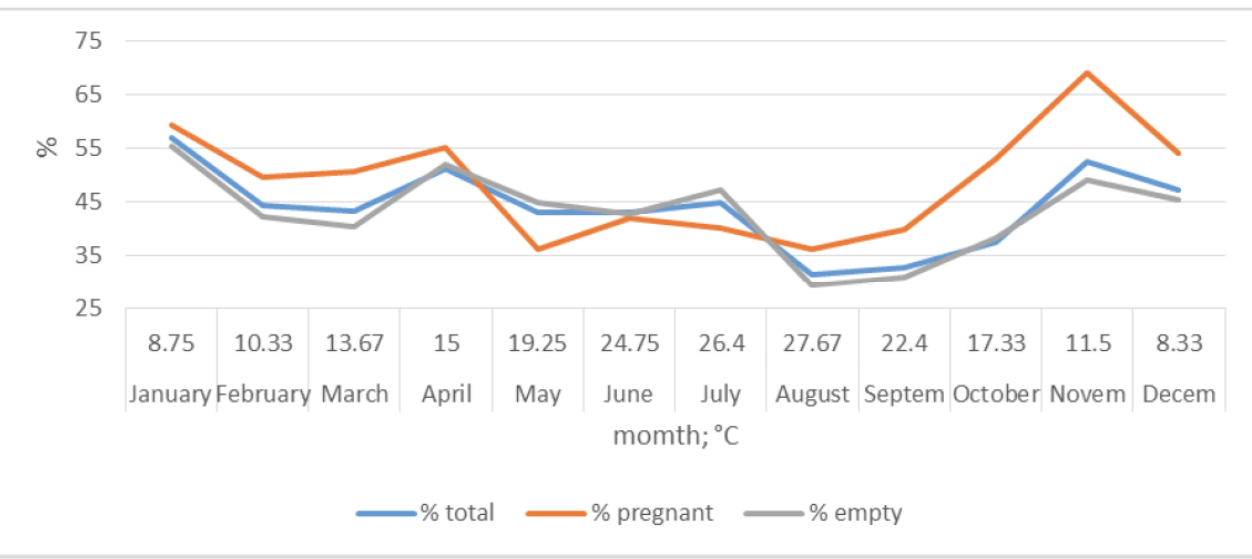

Figure 3: Percentage of buffaloes with monthly reduced production in 2017 (\%).

Table 3: Average Monthly Temperature in 2018 and Total Decrease Rate (\% Total) and Relative to Pregnant Ones (\% Pregnant) and Empty Ones (\% Empty) which Recorded a Decrease in Milk Production

\begin{tabular}{|c|c|c|c|c|}
\hline moonth & ${ }^{\circ} \mathbf{C}$ & \% total & 52.43 & \% pregnant empty \\
\hline \hline January & 11.20 & 52.03 & 48.31 & 51.75 \\
\hline February & 7.50 & 47.39 & 55.66 & 40.08 \\
\hline March & 11.40 & 44.69 & 48.33 & 38.49 \\
\hline April & 17.10 & 40.38 & 36.49 & 38.37 \\
\hline May & 19.80 & 37.93 & 41.57 & 42.39 \\
\hline June & 24.10 & 45.59 & 34.04 & 32.33 \\
\hline July & 26.60 & 32.62 & 26.21 & 32.43 \\
\hline August & 25.90 & 31.06 & 37.23 & 40.88 \\
\hline September & 22.80 & 39.95 & 40.00 & 30.17 \\
\hline October & 19.70 & 32.69 & 57.26 & 40.89 \\
\hline November & 14.10 & 45.78 & 49.51 & 47.01 \\
\hline December & 9.20 & 47.76 & $-0.828 * * *$ & $-0.759 * * *$ \\
\hline Value of "r" & & $-0.773 * * *$ & & \\
\hline
\end{tabular}

**** $\mathrm{P}<0.001 ;{ }^{* * *} \mathrm{P}<0.01 ;{ }^{* *} \mathrm{P}<0.05 ;{ }^{*} \mathrm{P}<0.05 \div 0.1$

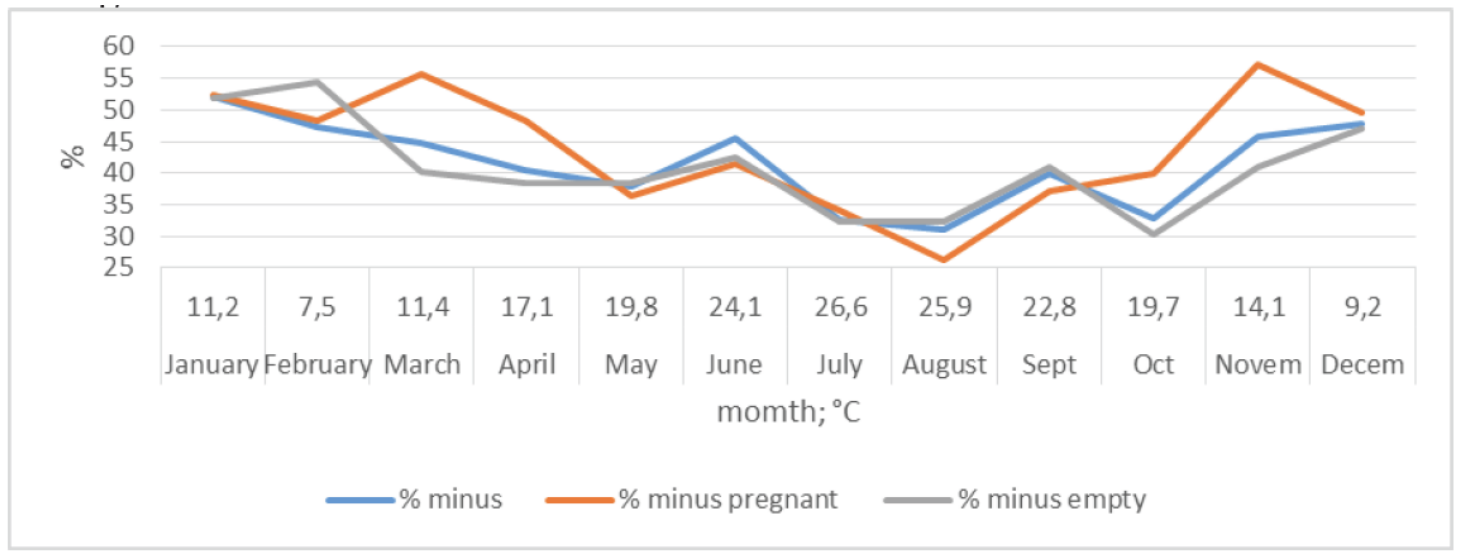

Figure 4: Percentage of buffaloes with monthly reduced production in 2018 (\%). 
Table 4: Average Monthly Temperature in 2019 and Total Decrease Rate (\% Total) and Relative to Pregnant Ones (\% Pregnant) and Empty Ones (\% Empty) which Recorded a Decrease in Milk Production

\begin{tabular}{|c|c|c|c|c|}
\hline & ${ }^{\circ} \mathbf{C}$ & \% minus & \% pregnant & \% empty \\
\hline \hline January & 5.90 & 41.22 & 46.83 & 56.03 \\
\hline February & 8.40 & 40.00 & 71.88 & 28.65 \\
\hline March & 11.60 & 40.08 & 28.57 & 27.36 \\
\hline April & 13.90 & 27.74 & 33.33 & 34.15 \\
\hline May & 16.20 & 28.95 & 23.97 & 24.32 \\
\hline June & 25.20 & 23.43 & 29.37 & 30.93 \\
\hline July & 27.40 & 30.49 & 19.19 & 27.89 \\
\hline August & 27.10 & 25.65 & 13.93 & 23.05 \\
\hline September & 23.90 & 20.61 & 22.29 & 30.21 \\
\hline October & 19.80 & 28.44 & 39.16 & 36.67 \\
\hline November & 14.40 & 37.36 & 50.45 & 48.20 \\
\hline December & 10.40 & 49.10 & $-0.773^{* * *}$ & $-0.543^{*}$ \\
\hline Value of " $r$ ( & & $-0.795^{* * *}$ & \\
\hline
\end{tabular}

**** $\mathrm{P}<0.001 ;{ }^{* * *} \mathrm{P}<0.01 ;{ }^{* *} \mathrm{P}<0.05 ;{ }^{*} \mathrm{P}<0.05 \div 0.1$.

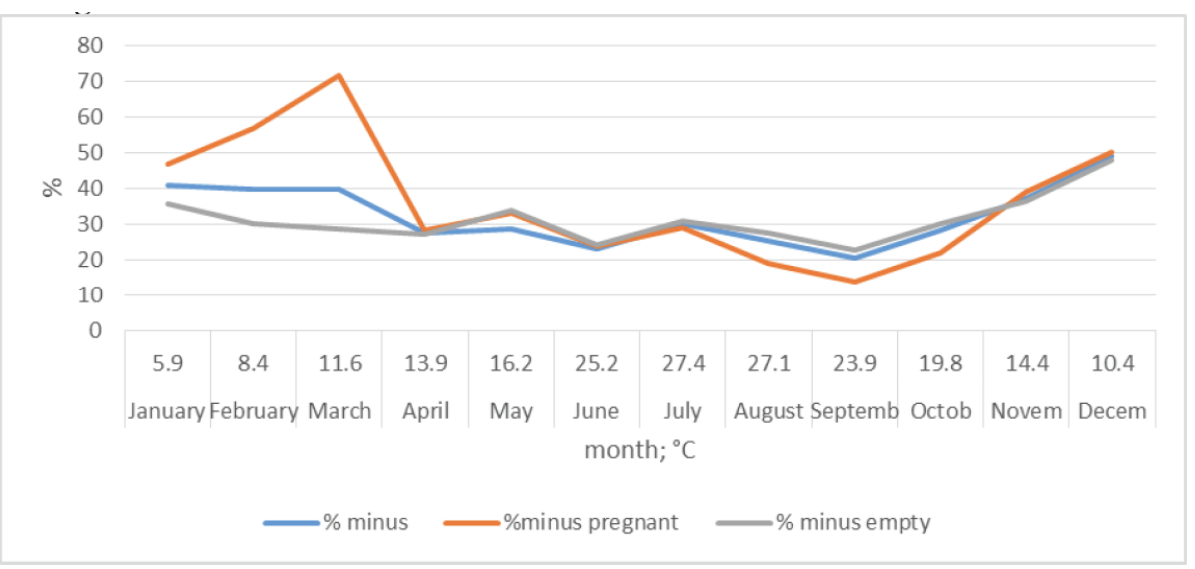

Figure 5: Percentage of buffaloes with monthly reduced production in 2019 (\%).

Table 5: Average Monthly Temperature in 2020 and Total Decrease Rate (\% Total) and Relative to Pregnant Ones (\% Pregnant) and Empty Ones (\% Empty) which Recorded a Decrease in Milk Production

\begin{tabular}{|c|c|c|c|c|}
\hline & ${ }^{\circ} \mathbf{C}$ & \% total & \% pregnant & \% empty \\
\hline \hline January & 13.2 & 24.96 & 24.65 & 26.62 \\
\hline February & 10.5 & 27.97 & 38.96 & 21.51 \\
\hline March & 12.2 & 33.63 & 29.82 & 34.57 \\
\hline April & 14.2 & 32.17 & 25.51 & 23.92 \\
\hline May & 19.2 & 17.79 & 6.84 & 26.10 \\
\hline June & 25.2 & 21.54 & 11.02 & 37.50 \\
\hline July & 26.2 & 36.59 & 35.42 & 24.51 \\
\hline August & 26.7 & 21.20 & 17.14 & 19.44 \\
\hline September & 21.5 & 16.70 & 25.43 & 19.43 \\
\hline October & 17 & 22.63 & 42.05 & 33.03 \\
\hline November & 13.2 & 38.24 & 39.23 & 35.86 \\
\hline December & 8.8 & 37.45 & -0.592 & \\
\hline Value of "r" & & -0.469 & & \\
\hline
\end{tabular}




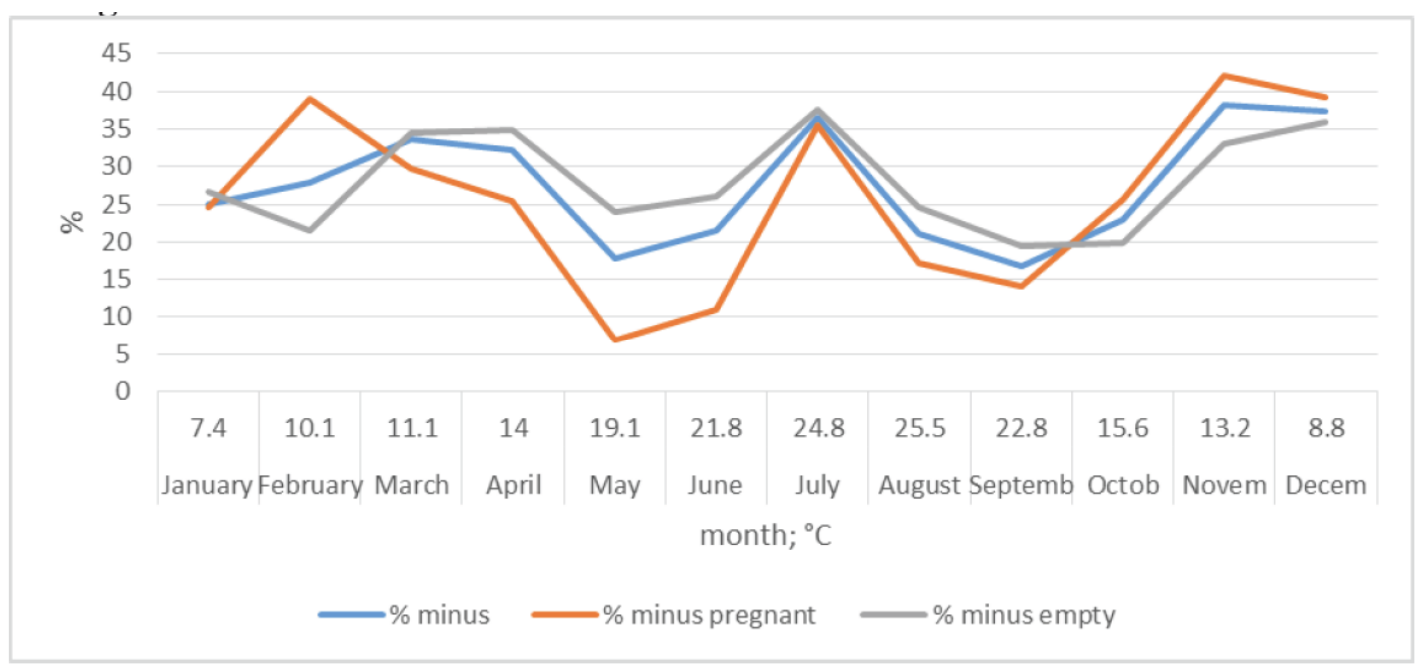

Figure 6: Percentage of buffaloes with monthly reduced production in 2020 (\%).

Table 6: Percentage of Subjects with Decreased Production between Temperatures $\left({ }^{\circ} \mathrm{C}\right)$ above and below the Mean as a Function of Years

\begin{tabular}{|c|c|c|c|c|}
\hline year & ${ }^{\circ} \mathrm{C}$ & $\%$ total & $\%$ pregnant & $\%$ open \\
\hline 2017 & $13.02 \mathrm{~A}$ & $47.08 \mathrm{a}$ & $53.47 \mathrm{a}$ & $46.02 \mathrm{c}$ \\
\hline \multirow[t]{2}{*}{2018} & $12.89 \mathrm{~A}$ & $44.39 \mathrm{c}$ & $50.22 \mathrm{~A}$ & 43.25 \\
\hline & $25.10 \mathrm{~B}$ & $37.43 \mathrm{~d}$ & $35.11 \mathrm{~B}$ & 37.28 \\
\hline 2019 & 24.68 B & $25.72 b$ & $21.75 b$ & $27.28 d$ \\
\hline \multirow[t]{2}{*}{2020} & $13.54 \mathrm{~A}$ & 29.36 & 29.06 & 28.72 \\
\hline & $24.90 \mathrm{~B}$ & 24.01 & 19.41 & 26.89 \\
\hline total & 12.19 & 39.18 & $44.70 \mathrm{a}$ & 30.90 \\
\hline
\end{tabular}

A, B P $<0,01 ; a, b P<0,05 ; c, d P<0,05 \div 0,1$.

Table 7: Percentage of Subjects who Decreased Production as a Function of the Average Monthly Temperature and the Lowering of each ${ }^{\circ} \mathrm{C}$ of Temperature

\begin{tabular}{|c|c|c|c|}
\hline${ }^{\circ} \mathrm{C}$; month & $\%$ total & $\%$ pregnant & $\%$ empty \\
\hline 8.13 & 41.22 & 46.83 & 36.03 \\
\hline 18.38 & 32.17 & 33.58 & 33.11 \\
\hline 23.24 & 33.16 & 31.44 & 33.28 \\
\hline Percentage decrease for each ${ }^{\circ} \mathrm{C}$ & -0.62 & -1.07 & -0.26 \\
\hline
\end{tabular}




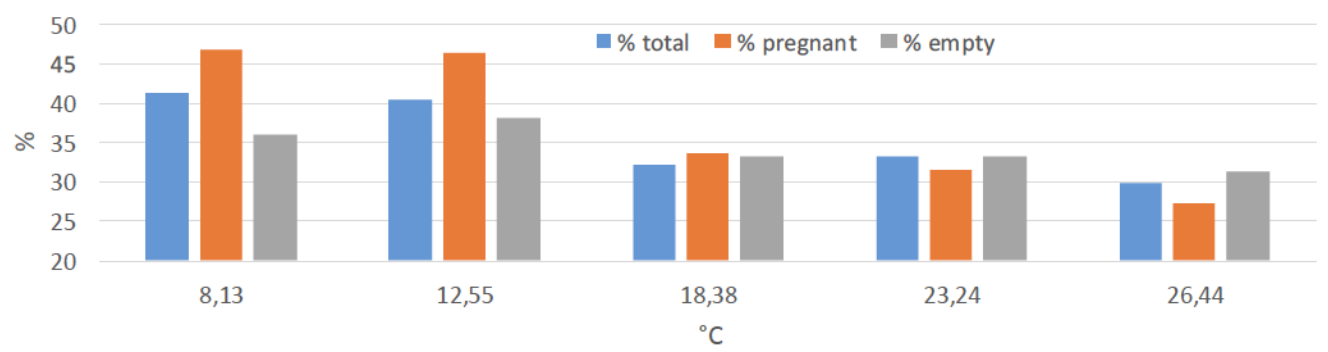

Figure 7: Percentage of subject with decreased production as a function of the average monthly temperature.

\section{DISCUSSION AND CONCLUSIONS}

This study showed that in areas where the temperature drops below $19^{\circ} \mathrm{C}$ in the colder months, there is a decrease in milk production, confirming the tropical origin of the buffalo. The phenomenon was more evident in pregnant females than in empty ones, especially below $19^{\circ} \mathrm{C}$, while it was not observed at higher temperatures. In women, as is known, the increase in progesterone during pregnancy stimulates the hypothalamic thermoregulatory centers, which cause a slight increase in body temperature, which leads to a sensation of cold and the onset of chills. There are no reports of a similar phenomenon in domestic ruminants.

In temperate areas where winters are cold, buffaloes react to low temperatures differently than cattle. In fact, milk production decreases as well as reproductive efficiency also for reasons related to the photoperiod. The dietary measures used so far have not given appreciable results. The structural interventions, on the other hand, were more valid. Pools have proven useful in mitigating the effects of high temperatures on fertility, and the availability of soft straw bedding has reduced the negative influence of low temperatures on milk production. These results show that this ruminant, until now considered rustic, is particularly sensitive to those devices that guarantee its well-being.

\section{ACKNOWLEDGMENTS}

The authors thank SOCIETA 'AGRICOLA GAROFALO S.R.L. to make case studies available.

\section{REFERENCES}

[1] http://faostat.fao.org/faostat, 2018

[2] Zicarelli L. Reproductive seasonality in buffalo. In: Proceedings of Third International Course of Biotechnology in Buffalo Reproduction, Napoli 6-10 October. Bubalus Bubalis 1997; 4(Suppl): 29-52.

[3] Zicarelli L. Influence of season on buffalo production. In: The Buffalo (Bubalus bubalis) - 373 Production and Research (G.A. Presicce, Editor), Bentham Books 2017; 196-224. https://doi.org/10.2174/9781681084176117010011

[4] Campanile G, Avallone L, D'Angelo A, Di Palo R, Di Meo C. Influence of the season and of the number of days after calving on the pattern of thyroid hormones in buffalo cows. Fourth World Buff Cong 1994; 3 : 564-66.

[5] Campanile G, Balestrieri ML. Interaction of environmental factors for better production in buffaloes. In Proc. 1th Buffalo Symposium of Americas, Belém (Brazil), 2002; 287-297.

[6] D'Occhio MJ, Ghuman S, Neglia G, Della Valle G, Baruselli PS, Zicarelli L, Visintin JA, Sarkar M, Campanile G. Exogenous and endogenous factors in the seasonality of reproduction in buffalo: A review 2020; theriogenology.2020.01.044. Epub 2020 Jan 23.

[7] Zicarelli, F, Campanile, G, Gasparrini, B, Di Palo, R, Zicarelli, L. Influence of the period and of the space on the milk production and on the consumption of dry matter in the Italian Mediterranean Buffalo. In: Proc. 3rd Congresso Nazionale sull'Allevamento del Buffalo-1st Buffalo Symp. Europe and the Americas, Paestum, (SA), Italy, 2005; pp. 75-76.

[8] Luigi Zicarelli, La bufala da latte, 30 giorni, agosto 2008; pp. 79-82.

[9] De Carlo E, Zicarelli L, De Rosa G. Wellness in the buffalo, Library of the Experimental Zooprophylactic Institute of Umbria and March Animal Welfare Edition: 2010 edited by: Fulvio Biancifiori 2010.

[10] it.wikipedia.org >wiki> Razza_bovina_Piemontese

[11] www.agraria.org >razzebovinelattes jersey

[12] Avallone L, Parmeggiani A, Esposito L, Campanile G. Correlation between Prolactin, T3 and T4 levels in buffalo heifers during the whole year. In Proc. IV World Buffalo Congress, Sao Paolo 1994; 2: 477-479.

[13] Grasso F, De Rosa G, Napolitano F. The comfort of the buffalo is linked to water. IZ 2008; 2: 72-74

[14] Neglia G, Rendina M, Balestrieri A, Grasso FL, Potena A, Russo I, Zicarelli L. Influence of a swimming-pool on fertility in buffalo species. Ital J Anim Sci 2009; 8(suppl. 2): 637-639. https://doi.org/10.4081/ijas.2009.s2.637

[15] Di Palo R, Ariota B, Zicarelli F, De Blasi M, Zicarelli G, Gasparrini B. Incidence of pregnancy failures in buffaloes with different rearing systems. Ital J Anim Sci 2009; 8(suppl. 2): 619-621. https://doi.org/10.4081/ijas.2009.s2.619

[16] https://www.ilmeteo.it/portale/ enforcement-meteo / Francolise / year / month / day fresh_ce.

https://doi.org/10.6000/1927-520X.2021.10.06

(C) 2021 Luigi Zicarelli; Licensee Lifescience Global.

This is an open access article licensed under the terms of the Creative Commons Attribution Non-Commercial License (http://creativecommons.org/licenses/by-nc/3.0/) which permits unrestricted, non-commercial use, distribution and reproduction in any medium, provided the work is properly cited. 